\title{
Itseohjautuvan työssä oppimisen ihanuus ja ongelmallisuus
}

\section{Kohti sosiokulttuurista näkökulmaa}

\author{
1 \\ Itseohjautuvaa oppimista korostetaan etenkin aikuisten elämässä \\ ja työssä. Usein se kuvataan myönteisenä, yksilölähtöisenä \\ toimintana, jonka kautta itseohjautuvat aikuiset innostuvat, \\ tuottavat luovia lopputuloksia ja voivat hyvin. Yksilölähtöisyys \\ jättää kuitenkin huomiotta yhteisöllisyyden ja ympäristön \\ merkityksen. Itseohjautuvaa oppimista tulisi lähestyä enemmänkin \\ sosiokulttuurisesta kuin yksilöllisestä näkökulmasta.
}

AMERIKKALAINEN KASVATUSTIETEILIJÄ Malcom Knowles kirjoitti vuonna 1950, että aikuiset oppivat parhaiten informaalissa, vapaassa ympäristössä, kuten työpaikoilla. Emme opi työelämässä enää vain siksi, että tarvitsemme yksittäistä taitoa tai siksi, että kehitämme itseämme uralla etenemisen vuoksi vaan myös siksi, että selviytyisimme arkisista ongelmanratkaisutilanteista ja työstämme. Työelämän muutos, globaali kilpailu ja teknologioiden jatkuva kehittyminen myös tuottavat jatkuvasti uusia oppimistarpeita.

Opetusministeri Li Anderssonin (vas.) valtiosihteeri Minna Kelhä (2019) kommentoi Valtioneuvoston jatkuvan oppimisen tutkijatapaamisessa, että "osaamisen kehittämistä työelämässä ajatellaan edelleen erillisenä kokonaisuutena, vaikka oppimisen pitäisi sisältyä työhön”. Tutkimuksissa onkin todettu, että jopa 80 prosenttia oppimisesta työssä tai työn vuoksi tapahtuu työtä tehdessä (esim. Yeo 2008). Siksi tarvitsemme formaalin, muodollisen koulutuksen rinnalle ymmärrystä aikuisten oppimisesta työn arjessa.

Samaan aikaan kun oppimisen vaateet kasvavat, yhteiskunnassamme vallitsee yksilökeskeisyyden eetos (Beck 2016). Se korostaa yksilöiden omaehtoisuutta ja oman elämän hallitsevuutta (Noe \& Ellingson 2017). Tähän näkökulmaan nivoutuu itseohjautuvuus, yksilöiden vastuunotto. Työ edustaa yksilöllisten tarpeiden ja autonomian toteutumista, ja vastuu työstä ja päätöksenteosta siirtyy 
organisaatioilta työntekijöille (Ellinger 2008; Noe \& Ellingson 2017; Rigby \& Ryan 2018).

Ilmiön taustalla on tehokkuuden ja kilpailukyvyn tavoittelu: kun yksilöt ottavat vastuuta omasta toiminnastaan, prosessit ovat nopeampia, ja kysyntään vastataan joustavammin (Lee \& Edmondson 2017). Samalla tavalla oppimisen tutkimuksessa on havaittu, että vastuu oppimisesta työssä on kallistunut yhä vahvemmin työntekijöille itselleen (Ellinger 2004). Kun tämä yhdistetään kasvaviin oppimistarpeisiin, on selvää, että juuri itseohjautuvasta työssä oppimisesta on tullut merkittävä työelämän ilmiö.

Työntekijöiltä odotetaan itseohjautuvaa toimintaa ja oppimista, joka on usein nähty aikuiselle ominaisena taitona ja kykynä (katso esim. Guglielmino 2008; Merriam 2001). Eri ihmisillä onkin erilaiset henkilökohtaiset, esimerkiksi kokemukseen, koulutukseen ja persoonallisuuteen liittyvät valmiudet toimia itseohjautuvasti (esim. Guglielmino 2008). Itseohjautuva oppiminen on kuvattu myös prosessiksi, jossa yksilö asettaa tavoitteet oppimiselleen sekä kontrolloi ja arvioi itse omaa oppimistaan (Knowles 1975; Brockett \& Hiemstra 1991).

Yksilölähtöistä näkökulmaa on kuitenkin arvosteltu siitä, että se näkee aikuisen oppijan teknisesti pätevänä robottina, joka toimii irrallisena ympäristöstään (Merriam 2001). Vähemmän huomiota on kiinnitetty siihen, millaisia mahdollisuuksia ja rajoitteita työelämän tilanteet, yhteisöt ja ympäristöt aikuisten itseohjautuvalle oppimiselle todellisuudessa tarjoavat ja asettavat (esim. Baskett 1993; Bell 2017).

Itseohjautuvan työssä oppimisen luonteeseen pureutuvassa väitöskirjassani (Lemmetty 2020a) yhdistin itseohjautuvan oppimisen yksilölähtöiset näkökulmat laajempaan sosiokulttuuriseen viitekehykseen, jonka mukaan oppiminen toteutuu yksilön, yhteisön ja ympäristön vuorovaikutuksessa (Vygotsky 1978; Billett 2004). Tutkimuksessa tarkastelin siten työntekijöiden oman toiminnan lisäksi organisaation kulttuuriin ja käytäntöihin, rakenteisiin, toimijoiden rooleihin ja asemiin sekä vuorovaikutussuhteisiin ja työympäristöihin liittyviä tekijöitä hyödyntämällä etnografista tutkimusstrategiaa (Hammersley \& Atkinson 2007).
Tutkimuksen taustalla vaikuttivat andragogiikan (esim. Knowles 1975; Knowles ym. 2012; Brocket \& Hiemstra, 1991), käytäntöperustaisen työssä oppimisen (esim. Billett 2004; Collin 2005) sekä luovan toiminnan (esim. Glaveanu 2015) teoreettiset viitekehykset. Tutkimuksen kohdeorganisaatiot toimivat teknologia-alalla, jossa niin oppimisen kuin itseohjautuvuuden ilmiöt ovat keskeisiä. "Itseoppimista tapahtuu joka päivä - se on oikeastaan mun työtä", kuvasikin eräs tutkimukseen haastateltu ohjelmistosuunnittelija. Väitöskirjani tuotti mielenkiintoisia näkökulmia itseohjautuvan oppimisen ilmenemisestä ja tukemisen keinoista työn arjessa, minkä vuoksi jatkan keskustelua havaintojeni ja löydösteni pohjalta.

\section{YKSILÖKESKEINEN ITSEOHJAUTUVUUS ON TYÖSSÄ OPPIMISEN ILLUUSIO}

Tutkimukseni vahvistaa oletuksen, että itseohjautuva oppiminen on sosiokulttuurinen ilmiö, jossa yksilön tai ryhmän vastuunotto kiinnittyy ympäristön ja yhteisön raameihin (Lemmetty 2020a). Tästä syystä autonominen, yksilökeskeinen itseohjautuvuus on työelämässä mahdotonta: yksilö on työssä aina osa suurempaa sosiokulttuurista kokonaisuutta. Siksi myöskään itseohjautuvaa oppimista ei pitäisi tulkita yksiselitteisesti yksilön hallitsemaksi toiminnaksi, vaan samalla on otettava huomioon itseohjautuvuutta mahdollistavat ja rajoittavat tilanne- ja organisaatiokohtaiset tekijät (Lemmetty 2020b). Teknologia-alan työssä oppiminen saattaa näyttäytyä yksinäisenä puurtamisena. Todellisuudessa tietokoneen ruudulla tai projektitiimin loosissa on käynnissä monia keskusteluita kollegoiden tai lähijohtajien kanssa. Ilman näitä keskusteluja oppimisprosessit hidastuisivat ja tyrehtyisivät. Itseohjautuva oppiminenkaan ei siten ole yksinäistä työskentelyä.

Työssä oppiminen voi toteutua luovuutta ja hyvinvointia lisäävänä ilmiönä (Lemmetty 2020a). Tämä havainto osuu yleisen oppimisdiskurssin ytimeen: oppiminen on myönteinen asia. Oppiessamme koemme hienoja tunteita itsemme ylittämisestä. Itseä kiinnostavan aiheen parissa pääsemme flow-tilaan, jossa aika kuluu kuin siivillä.

Oppiminen kulkeekin käsi kädessä luovan toiminnan kanssa (Lemmetty \& Collin 2020). On opittava 


\section{PuitTeita KEHITT $\ddot{A} M \ddot{A} L L \ddot{A}$}

\section{ORGANISAATIOT VOIVAT}

VAIKUTTAA SIIHEN,

MILLAISEKSI ITSEOHJAUTUVA

OPPIMINEN TYÖSS $\ddot{A}$

MUODOSTUU.

jotain, että ongelman saa ratkaistua. Jokainen meistä on törmännyt esimerkiksi rekrytointi-ilmoituksiin, joissa hakijalta odotetaan "halua oppia ja kehittyä". Työpaikoille halutaan työntekijöitä, jotka nauttivat oppimisesta ja motivoituvat uusista asioista ja taidoista. Nämä odotukset eivät silti automaattisesti takaa positiivisia oppimiskokemuksia.

Oppiminen voi nimittäin yhtä lailla olla kuormittavaa ja ongelmallista: kiireen ja muutoksen tuottama oppimisähky voi verottaa hyvinvointia ja motivaatiota. Teknologia-alan työntekijöiden puheesta rakentui kuva jatkuvan, jokapäiväisen oppimisen välttämättömyydestä. Erään haastateltavan mukaan kaksi kuukautta ilman uuden opettelua takaa sen, ettei osaa enää mitään hyödyllistä. (Lemmetty \& Collin 2019.) Alalla muutos on siis erityisen rajua. Mutta aivan ennenkuulumatonta tämä ei ole muillakaan toimialoilla: uusia tietojärjestelmiä, toimintatapoja tai vaatimuksia pongahtaa eteen tuon tuosta.

Työntekijät tuskailevat työn lisääntyvien häiriötekijöiden ristitulessa, yrittäen löytää päivästä, viikosta tai kuukaudesta rakoa suurten kokonaisuuksien oppimiselle. Siksi tutkimushavainnot siitä, että monilla organisaatioilla voi olla vähäiset resurssit ja kapea ymmärrys työntekijöiden oppimisen tukemiseen (esim. Lizier \& Reich 2019), näyttää huonolta yhtälöltä. Ongelmia on tiedossa erityisesti siinä vaiheessa, kun oppimista ei nähdä osana työntekijän työtä vaan se verhotaan ainoastaan itsensä kehittämisen, oman markkina-arvon säilyttämisen ja itseen sijoittamisen alle. Toki oppiminen on panostusta omaan jaksamiseen ja urakehitykseen, mutta se on myös panostamista organisaation kilpailukykyyn. Siksi ei voi olla niin, että oppimisesta tulee sellainen työn osa, jota odotetaan automaattisesti teh- tävän omalla ajalla, pahimmassa tapauksessa perheen ja omien harrastusten kustannuksella.

Työssä oppimisen ongelmallisuutta koskee tutkimushavainto, jonka mukaan oppiminen voi olla työntekijälle kuormittavaa ja jopa hyvinvointia uhkaavaa (Lemmetty 2020a). Se ei ole ainutlaatuinen. Euroopan työterveys- ja työturvallisuusviraston (2019) julkaisemassa raportissa nimittäin mainitaan kehittyväksi työterveys- ja turvallisuusriskiksi digitalisaation aiheuttama jatkuvan oppimisen tarve. Elämme käänteentekevää aikakautta: oppimisesta on tulossa työterveysriski.

Tutkimusten mukaan itseohjautuva työssä oppiminen on sekä paradoksaalinen että sosiokulttuurinen ilmiö (Lemmetty \& Collin 2019; Lemmetty 2020a). Se voi edistää luovaa toimintaa ja olla siten tuottavaa mutta yhtä lailla toteutua kuormittavana ja toimijoiden hyvinvointia haastavana. Arjen nopeissa tilanteissa työntekijä ottaa vastuuta ja tekee päätöksiä aktiivisesti, mutta ei kuitenkaan toimi tyhjiössä. Ympäristö asettaa toiminnalle mahdollisuudet ja puitteet (Lemmetty \& Collin 2020; Lemmetty 2020b). Puitteita kehittämällä organisaatiot voivat vaikuttaa siihen, millaiseksi itseohjautuva oppiminen työssä muodostuu: synnyttääkö se luovaa toimintaa ja on siten tuottoisaa vai ajaako se työntekijät ongelmia tuottavaan ahdinkoon?

Koska oppiminen ei voi olla täysin yksilöllistä, työpaikoillakaan ei riitä, että vain palkataan luovia, oppivia, itsensä johtamisen taidoilla varustettuja yksilöitä, vaan heidän tulee lisäksi ymmärtää, mihin he omaa oppimistaan suuntaavat ja mitä mahdollisuuksia heillä on käytettävissään. Kun organisaatiot jatkuvasti muuttuvat, myös mahdollisuudet itseohjautuvalle oppimiselle muuttuvat. Muutosta ei aina voi jarruttaa, mutta työpaikoilla on syytä pitää huolta esimerkiksi siitä, että organisaation rakenteet ja vastuualueet ovat selviä. Tällöin työntekijä tietää, keneltä saa apua.

Kontrolloivan esimiestyön sijaan valmentava, työntekijälähtöinen lähijohtaminen on tärkeää itseohjautuvan oppimisen tukemisessa. Lähijohtajia tarvitaan asiantuntijatyössäkin hahmottamaan kokonaiskuvaa sekä jakamaan vastuuta ja työtaakkaa. Vuorovaikutustilanteiden mahdollistaminen edistää asiantuntijoiden välistä kokemusten jakamista. 
Jos itseohjautuva oppiminen alkaa esiintyä yhä vahvemmin yksinäisenä työskentelynä tai yksilöiden hartioille kasaantuvana kuormana, tehokkuuden ja suorittamisen haasteiksi muodostuvat sekä vaikeudet auttaa toisia että yksinkertaisesti aika. Oppiminen vaatii aikaa, ja se tulisi huomioida työtehtävien aikataulutuksessa ja resurssien suunnittelussa. Toisaalta oppimisaikaa voi joskus lisätä sillä, että kaikkea ei tehdä luovasti: valmis ohje, kaavio tai ratkaisu saattaa tuoda työntekijälle juuri sen kriittisen hengähdyshetken, joka mahdollistaa tärkeän oppimiskokemuksen.

\section{ITSEOHJAUTUVUUDEN KOROSTUMINEN TYÖELÄMÄSSÄ JA YHTEISKUNNASSA}

Vuoden 2020 uutisotsikoissa on vilissyt havaintoja siitä, miten koronavuosi etätöineen on vaikuttanut työntekijöihin. Toiset ovat nauttineet uudenlaisen vapauden tuomasta työmotivaatiosta, kun taas toiset ovat kokenet yksinäisyyttä tai tuen puutetta. Etäelämä ei siis olekaan ollut pelkkää auvoista autonomiaa, kuten ei elämä yleensäkään.

Yksilökeskeisen yhteiskunnan ongelma onkin sellaisen itseohjautuvuuden odotus, joka pedataan innostaviin mielikuviin vapaudesta ja yksilön kaikkivoipaisuudesta. Monista työssä saavutetuista lopputuloksista sataa kunniaa yksittäisille tekijöille työpaikoilla ja sosiaalisessa mediassa. Koska harvoin uhraamme aikaamme kysymykselle, miten tulokset todellisuudessa syntyivät, ne jäävät yksilösuorituksina ja sankaritarinoina vahvistamaan todeksi illuu- siota yksilön riippumattomuudesta. Näin tulemme luoneeksi kulttuuria, jossa myös kuvittelemme, että meidän tulee pärjätä yksin. Todellisuudessa elämme yhteisöissä, ja muuttuvan maailman ympäröimänä olemme yhä riippuvaisempia toisistamme. Yksin selviytymisen sijaan itseohjautuvuus tulisi nähdä yksilön aktiivisuutena, joka pilkahtelee yhteisöllisen oppimisen kokonaisuudessa tuettuna.

Siksi organisaatioissa on perusteltua kehottaa tarkastelemaan sitä, missä tilanteissa on tarkoituksenmukaista luoda odotuksia yksilöiden mittavalle vastuun ottamiselle, ja milloin olisi otollisempaa vaalia pikemminkin yhteisen tekemisen lomassa rakentuvaa aktiivisuutta. Turbulentin työelämän voittajia ovat ne organisaatiot, joissa kyetään löytämään niin yksilöä, yhteisöä kuin organisaatiotakin laajasti palvelevia yhteisiä päämääriä, käytäntöjä ja toimintatapoja. Joissa työpaikat itsessään nähdään oppimisympäristöinä, työntekijät oppijoina ja johtajat oppimisen ohjaajina.

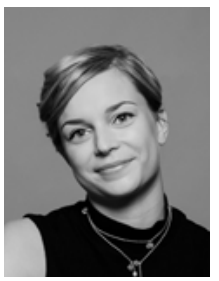

\section{SOILA LEMMETTY}

$\mathrm{KT}$, tutkija

kasvatustieteiden laitos Jyväskylän yliopisto

(D) https://orcid.org/0000-00033367-8718

Näkökulmateksti perustuu Soila Lemmetyn aikuiskasvatustieteen väitöskirjan "Self-learning is present every day - in fact, it's my job". Self-directed workplace learning in technology-based work lektioon. Se tarkastettiin syyskuussa 2020 Jyväskylän yliopistossa.

\section{LÄHTEET}

Artis, A. B. \& Harris, E. G. (2007). Self-directed learning and sales force performance: An integrated framework. Journal of Personal Selling and Sales Management 27(1), 9-24. DOI: doi.org/10.2753/ PSS0885-3134270101.

Baskett, H. K. M. (1993). Workplace factors which enhance self-directed learning, 7th International Symposium on Self-Directed Learning, West Palm Beach, FL, USA. 21.-23.1.1993. https://files.eric. ed.gov/fulltext/ED359354.pdf.

Beck, U. (2016). Varieties of second modernity and the cosmopolitan vision. Theory, Culture and Society 33(7-8), 257-240. DOI: doi. org/10.1177/0263276416671585.

Bell, B. S. (2017). Strategies for supporting selfregulation during self-directed learning in the workplace. Teoksessa R. A. Noe \& J. E. Ellingson (toim.). Autonomous learning in the workplace. New York, NY, USA: Routledge, 117-134. DOI: doi. org/10.4324/9781315674131.

Billett, S. (2004). Learning through work: Workplace participatory practices. Teoksessa H. Rainbird, A. Fuller \& A. Munro (toim). Workplace learning in context. London: Routledge, 109-125. 
Brockett, R. G. \& Hiemstra, R. (1991). Self-direction in adult learning: Perspectives on theory, research, and practice. London: Routledge.

Collin, K. (2005). Experience and shared practice - design engineers' learning at work (Doctoral dissertation, Jyväskylä studies in education, psychology and social research 261, University of Jyväskylä, Jyväskylä, Finland). https://jyx.jyu.fi/ bitstream/handle/123456789/13310/9513921883. pdf? sequence $=1$ \&isAllowed $=y$.

Ellinger, A. D. (2004). The concept of self-directed learning and its implications for human resource development. Advances in Developing Human Resources 6(2), 158-177. DOI: doi. org/10.1177/1523422304263327.

Euroopan työterveys ja työturvallisuusvirasto (2019). Kyselytutkimus Euroopan yrityksille uusista ja kehittyvistä riskeistä -raportti. https://osha.europa.eu/ fi/facts-and-figures/esener (4.9.2020).

Glăveanu, V. P. (2015). Creativity as a sociocultural act. The Journal of Creative Behavior 49(3), 165-180. DOI: doi.org/10.1002/jocb.94.

Guglielmino, L. (2008). Why self-directed learning? International Journal of Self-Directed Learning 5(1), $1-12$.

Hammersley, M. \& Atkinson, P. (2007). Ethnography: Principles in practice. London: Roudledge.

Kelhä, M. (2019). Kommentti jatkuvan oppimisen uudistuksen tutkijatapaamisessa 26.11.2019. https://www.sitra.fi/artikkelit/elinikaista-oppimistauudistetaan-tutkimustietoa-hyodyntaen/ (4.9.2020, tallenne katsottavissa).

Knowles, M. (1950). Informal Adult Education A Guide for Administrators, Leaders, and Teachers. New York, NY, USA: Association.

Knowles, M. (1975). Self-directed learning. Chicago, IL, USA: Follet.

Knowles, M., Holton, E. F. \& Swanson, R. A. (2012). The adult learner: The definitive classic in adult education and human resource development. London: Routledge.

Lee, M. Y. \& Edmondson, A. C. (2017). Self-managing organizations: Exploring the limits of less-hierarchical organizing. Research in Organizational Behavior 37, 35-58. DOI: doi.org/ 10.1016/j.riob.2017.10.002.

Lemmetty, S. \& Collin, K. (2019). Self-directed learning as a practice of workplace learning. Interpretative repertoires of self-directed learning in ICT work. Vocations and Learning 13, 47-70. DOI: doi. org/10.1007/s12186-019-09228-x.
Lemmetty, S. \& Collin, K. (2020). Self-directed learning in creative activity: An Ethnographic study in technology-based work. Journal of creative behaviour, early online. DOI: doi.org/10.1002/ jocb.438.

Lemmetty, S. (2020a). "Self-learning is present every day - in fact, it's my job". Self-directed workplace learning in technology-based work. Jyväskylä: Jyväskylän yliopisto.

Lemmetty, S. (2020b). Employee opportunities for self-directed learning at technology organizations: Features and frames of self-directed learning projects. Studies in Continuing Education, early online. DOI: doi.org/10.1080/0158037X.2020.1765758.

Lizier, A. \& Reich, A. (2019). "If you're not in the classroom, you're not learning": Workplace learning and structured learning and development systems and practices in complex adaptive organisations. Proceedings, Reasearching Work and Learning, 5th International Conference on Researching Work and Learning (RWL11). Giessen, Germany: Justus-von Liebig Universität, 47-48.

Merriam, S. (2001). Andragogy and self-directed learning: Pillars of adult learning theory. New Directions for Adult and Continuing Education 89, 3-13. DOI: doi.org/10.1002/ace.3.

Noe, R. A. \& Ellingson, J. E. (2017). Autonomous learning in the workplace: An introduction. Teoksessa J. E. Ellingson \& R. A. Noe (Toim.), Autonomous learning in the workplace. New York, NY, USA: Routledge, 1-12. DOI: doi.org/10.4324/9781315674131.

Paloniemi, S. \& Collin, K. (2010). Discursive power and creativity in inter-professional work. Vocations and Learning 5(1), 23-40. DOI: doi.org/10.1007/s12186011-9064-7.

Rigby, C. S. \& Ryan, R. M. (2018). Self-determination theory in human resource development: New directions and practical consideration. Advances of Developing Human Resources 20(2), 133-147.

Vygotsky, L. S. (1978). Mind in society. The development of higher psychological processes. Teoksessa M. Cole, V. John-Steiner, S. Scribner \& E. Souberman (Toim.), Mind in society. Cambridge, MA, USA: Harvard University, 19-58.

Yeo, R. K. (2008). How does learning (not) take place in problem-based learning activities in workplace contexts. Human Resource Development International 11(3), 317-330. DOI: doi. org/10.1080/13678860802102609. 